\title{
Industrial Relations in Kiribati
}

\author{
Kevin Hince *
}

This paper examines recent developments in industrial relations in Kiribati and questions the appropriateness of continuing with an industrial relations legislative framework, procedures and institutions that are a legacy of colonial rule. In recent years there have been moves to revamp this in keeping with local practices. Although the early period after independence brought a union-government confrontation, recent responses suggest that Kiribati may move towards a more pluralist, tripartite approach to industrial relations processes and institutions in the 1990s.

\section{Introduction}

Industrial relations in Kiribati in the 1990 s is still conducted primarily within the legislative framework, procedures and institutions devolved from the colonial past. Roberts (1964) outlines how such legislation, procedures and institutions were transplanted across the globe by virtue of the policies of the British Colonial Office and peripatetic colonial officers. Transplantation from the the home country or the more populous African and Asian colonies to the micro-states of the Pacific has been questioned (Hince, 1971). The relevance of such transplanted ideas in the post-colonial independence era of those micro-states is even more questionable.

Kiribati, which had been the Gilbert Islands part of the Gilbert and Ellice Islands colony became independent from Great Britain in 1979. However, the government of independent Kiribati has retained a similar paternalistic attitude to labour relations as that of the colonial predecessors, and continued to work within the inherited legislative framework. Little effort has been made by government to question, alter or adapt pre-independence legislation. Further, there has been minimal overt encouragement and recognition for a positive role for trade unions. The response by government to the trauma of extended strike action in 1980 by a key union, the Botakin Karikirakean Aroia Tan Makuri union (BKATM), was a revision of procedures to tighten administrative control, and remove unions further from the processes of dispute resolution, both in determining terms and conditions of employment, and in processing grievances between employees and management that arise from time to time. This paper outlines the contemporary situation in respect to industrial relations, and identifies areas of current debate, approaching such issues via an understanding of key historical, especially post-independence, events.

Kevin Hince, Professor of Industrial Relations and Director: Industrial Relations Centre, Victoria University of Wellington. The author is indebted to Ngutu Awira (formerly General Secretary of the BKATM and KTUC) who first sparked my interest in unionism and industrial relations in Kiribati. Awira was the first i-Kiribati to undertake and complete the Diploma in Industrial Relations at Victoria University. His Diploma project (available in the Faculty of Commerce and Administration library) contains invaluable background material on the early development of industrial relations in Kiribati, especially the formation of the BKATM and the 1980 strike. Responsibility for material in this article remains mine. 
The next section of this paper introduces the geographic and economic context within which industrial relations in Kiribati occurs. The following sections introduce the extensive legislative basis inherited from the colonial government, the key events and outcomes of the BKATM strikes of 1980, the perceived inequities of these outcomes and further pressure for change that developed later in the 1980s. At the macro-level the ongoing debate can be viewed as a contest between the pluralism of organised labour and government in respect to the establishment of key national issues, (or the non-involvement of organised labour in such areas). Similarly, at the micro-level the debate relates to the primacy of managerial roles versus the pluralism of worker/union participation in grievance processing and operational aspects of business. Neither of these debates are unique to Kiribati, for both are central to the form of government/management/union relationships in the modern world. However, the context in which the debate occurs is different, if not unique.

\section{The context}

Kiribati is a micro-state in the truest sense of the term, except perhaps in respect to geographic area. Thirty-three islands, a land mass of 810 square kilometres, are scattered across 3.5 million square kilometres of ocean, extending some 3,000 kilometres east-west and 2,000 kilometres north-south, spanning the equator and the international date line. The republic comprises three main island groups, the Gilbert Islands, the Line Islands and the Phoenix Islands, and one isolated island, Banaba (formerly Ocean Island). All the islands, except Banaba, are atolls. Kiritimati (Christmas Island) in the Line Islands is 3,500 kilometres from Tarawa, the capital, located on South Tarawa Island in the Gilberts chain. The total population of Kiribati (1985) is 64,000 of whom 61,000 are in the Gilberts group, including 21,000 on South Tarawa. Approximately 95 percent of the population is Micronesian.

Economic dualism is a feature of productive activity and a monetised economy exists only in urban Tarawa and on Kiritimati Island. Public enterprise dominates the cash economy of urban Tarawa, and Kiritimati Island caters for a limited amount of tourism. A manufacturing sector is practically non-existent, and most private enterprise (taxis, movie-showing, food-vendors) is concentrated on South Tarawa. Exports are basically copra and marine products, whilst imports comprise a wide range of food, consumer and capital goods. Employment in the cash sector is 6,769 (1985) with two-thirds of these in South Tarawa. Nearly half of those employed in the cash sector are in "public administration", a further third in "wholesale and retail trading" and "transport and communication" (each dominated to date by government ownership). Manufacturing employment comprises two percent of employment, and agriculture and fishing seven percent.

Public sector employment encompasses the administrative public service, public works activities (power, water, sewerage, post and telecommunication, civil aviation, roads, port activities), health, education, and trading activities such as Air Tungaru, the shipping corporation and the Kiribati Oil Company. Most paid agricultural and fishing employment is in the government sector. The Sixth Development Plan for Kiribati (1987-91) refers to this concentration of employment, and implicitly identifies the core contemporary industrial relations issue for the country as one of "control", or alternatively a struggle for participatory involvement against such unilateral "control". The Plan (p. 106) records (my emphasis): 
Within the monetary sector the largest employer is the public sector. Through a national wage system it also controls the pay and conditions of employees in public corporations and companies. Approximately 70 percent of those employed in the monetary sector are employed in this "controlled" sector. Most of this employment is centred on South Tarawa.

Industrial relations and wage employment issues, and strike activity, first emerged in the phosphate mining operations of Ocean Island. However, phosphate mining ceased in 1978 and such issues, as with employment in the monetary sector, are now centred on the urbanised area of South Tarawa.

\section{Industrial relations legislation}

Three key statutes provide the legislative base for industrial relations, the Trade Union Ordinance Ch. 97 (1946), the Employment Ordinance Ch. 30 (1966) and the Industrial Relations Code Ch. 35 (1974). All are legacies of the colonial era.

\section{(i) Trade Union Ordinance}

The Trade Union Ordinance provides for the registration of trade unions. A minimum of seven workers can form a union. Registration is compulsory, and requires the submission of rules covering, among other matters, the name of the union, the objects, the provisions for making, altering or rescinding rules, appointment and removal of officers, and the keeping and accessibility of accounts. A list of titles and names of the officers must also be provided. Registration accords legitimacy to pursue the purposes of the organisation, together with responsibilities of financial accountability of officials. The protections of the Trade Union Act (UK) 1871 are extended to Kiribati unions by this ordinance. That is, the ordinance provides protection against prosecution for criminal conspiracy for action taken by unions, merely because the action is in restraint of trade. Similarly, the purpose of any trade union shall not, by reason merely that they are in restraint of trade be deemed unlawful. Further, there is the protection originating in the Trade Disputes Act (UK) 1906 of immunity from action for tort, and that action taken in combination in contemplation of furtherance of a trade dispute shall not be liable as conspiracy. The Ordinance also provides the basic provisions of freedom of association.

The Trade Union Ordinance was first introduced in 1946, not as part of any specific plan to encourage unionism, but as part of a general policy of the United Kingdom government to place such legislation on the statute books of all dependencies. No unions were registered under the ordinance until the 1970s.

The first union to operate in Kiribati was the Civil Services Association formed in 1953 as an affiliate of the British Civil Service Association. Both local and expatriate civil servants were members, and the association acted as an in-house consultative mechanism. It was not registered under the local legislation until 1974 (and then as the Public Employees Association). Increasing political consciousness, and the associated debates about independence and the possibility of separation from the Ellice Islands during the 1970s, were also key catalysts for the emergence and growth of trade unions. A most important first was that taken in 1971 with the formation of the BKATM (first registered in 1972) as a general union for employees in both the public and private sectors. It emerged from a linking of two 
separate associations formed in the late 1960s, the Public Works Department Staff Association and the Wholesale Society Trade Union. The immediate catalyst was the prospective reorganisation of all government trading activity into the Gilbert and Ellice Islands Development Authority (GEIDA). That reorganisation occurred in 1972. The Authority, at the time of formation, employed two-thirds of the paid work-force of the country.

By 1976 six unions had registered. In 1982 five unions became founding members of the Kiribati Trade Union Congress (KTUC), which in time affiliated with the International Confederation of Free Trade Unions. Table 1 lists the trade unions operating in 1989, together with estimates of membership.

\section{Table 1:Trade Union Membership - 1989}

\begin{tabular}{lr}
\hline Aia Union Taan Akawa I-Kiribati & 80 \\
Bank Workers Union & 35 \\
BKATM Union & 450 \\
Fanning Plantation Workers Union & 70 \\
Kiribati Co-operative Wholesale Society Workers Union & 70 \\
Kiribati Is. \& Tuvalu Overseas Seamen's Union (KIROSU) & 2,000 \\
Kiribati National Union of Teachers (KNUT) & 300 \\
Kiribati Nurses Association (KNA) & 65 \\
Kiritimati Is. Federation Workers Union & 210 \\
Nanolelei Co-Operative Society Workers Union (Retailers) & 30 \\
Pre-School Teachers Union & 45 \\
Public Employees Association (PEA) & 400 \\
Rural Workers Union - Butaritari Island & 250 \\
Rural Workers Union - Makin Island & 100 \\
& $-1,105$ \\
& 4,10 \\
\end{tabular}

Source: Figures supplied by KTUC modified by assessment of verbal evidence assembled during field work.

The union membership figures of table 1 are indicative, or approximate, rather than precise. For example, the figure of 2,000 members for the Overseas Seamen's Union approximates the number of registered seamen. At any one time only 20-25 percent of these would be employed and paying fees. Also the Kiritimati Is. Federation Workers Union had become inoperative by mid-1991. Nevertheless, even if the aggregate figure is discounted to the level of 2000-2500 members, this represents a membership penetration rate in the range of 30-40 percent. The Overseas Seamen's Union is one of two private sector unions, the other is the Bank Union. Accordingly the union membership penetration rate in the public sector is even higher, in the range of $40-50$ percent. The data, despite the potential discrepancies, does indicate a continuing union presence, and a commitment, especially amongst urban employees in the monetised sector, to the concept of unionism.

The KTUC operates with one paid full-time officer, an Education Officer (who undertakes most of the administrative tasks) and one office support worker. Other officers are honorary and part-time. Funding from overseas agencies is critical in the operating budget 
of the Congress. One aim of the KTUC is to rationalise the organisation of unions, moving towards a federal relationship of unions within a single structure. An interim step of rationalisation to five or six sector unions is currently at the planning stage. The BKATM and the Overseas Seamen's Union are the only individual unions to have a full-time paid official.

\section{The Employment Ordinance}

The Employment Ordinance, part of the package of colonial labour legislation, was introduced to the Gilbert Islands colony in 1966. The ordinance regulates the employment of women and children, prohibits forced labour, provides for written contracts of employment and regulates recruiting of labour. Standards of rationing, sanitary arrangements, housing and medical care are elaborated, together with procedures protecting the payment of labour. A minimum wage can be established under the Act. The office of Commissioner of Labour (replaced by the Ministry of Trade, Industry and Labour (MINTIL) at independence) was established to administer the ordinance.

The ordinance has provided a base or minimum set of employment conditions, and means of control against the worst cases of exploitation. However, it is argued (Awira, 1988, p.5) that the Employment Ordinance was an attempt by the administration to retain control of the determination of employment conditions and forestall the creation and development of unions. Certainly the record of government since independence has been to exercise such 'control'. The dominance of public sector employment together with the post-independence emergence of centralised formulations of wage and employment conditions under the title of National Conditions of Service, has meant the Employment Ordinance base relates primarily to the small proportion of employees in the private sector, (excluding overseas seamen where provisions are established externally under the International Transport Federation code), and particularly rural labour.

\section{The Industrial Relations Code}

By the early 1970 s an estimated 60 percent of the urban workforce were members of trade unions (Awira, 1988, p.6). Moreover, this was a time when the debate about the political future of the colony was developing, and local political leaders sought issues and constituencies. Employment conditions was one such issue and public employees (and trade unions of public employees) were an important constituency. The Industrial Relations Code, was introduced in 1974 to provide procedures for processing the trade (industrial) disputes that began to develop with increasing frequency in this period.

Under the ordinance trade disputes can be reported to the Minister who then has discretion whether to recognise the existence of that dispute, and then to choose a means to process the matter. If a trade dispute is recognised six options exist for further action. First, if the Minister believes that inadequate use of existing machinery has been made or inadequate negotiation has take place, the Minister may refer the matter for further attention by that machinery, or negotiation. Second, the Minister may refer the matter for further negotiation, making proposals to the parties about a possible basis for settlement. The third option is to provide for conciliation; the fourth, refer the matter to an arbitration tribunal, and the fifth, refer the matter to a board of inquiry. The final option is to refer the matter to an 
Incomes Commission. Further sections of the ordinance detail the composition, structures and operation of each of these options.

Clearly the provisions are comprehensive, but there lies, as illustrated later, the source of a critical contemporary problem for industrial relations in Kiribati. The provision is for a series of options, or alternative choices. Moreover, dispute settlement does not encompass a progression through processes, but potentially a sequence of choices. For example, if the initial method chosen, perhaps conciliation, fails, then a further choice of options can be exercised, perhaps arbitration or an inquiry. In addition the need for choice is multiplied within each of the primary procedures. For example, if the process of arbitration is selected there follows the options of sole arbitrator, an arbitrator assisted by one or more assessors, or one or more arbitrators selected from a pool agreed upon by employers and employees (or the trade union). Then the choice or selection of personnel need be made. All choices are made by a political office-holder, the Minister of Trade, Industry and Labour.

Strikes, lockouts and boycotts are illegal before procedures are exhausted. A strike in relation to an issue already settled (in the opinion of the Minister) by an unexpired agreement or an award is also illegal. Penalties of fines and imprisonment can be levied against individuals participating in an unlawful strike, lockout or boycott. The Code provides for a secret ballot to be taken prior to a strike, if the number of employees involved exceeds 50. A decision to strike requires a two-thirds majority of those eligible to vote. The ballot is conducted by the Commissioner of Labour (subsequently MINTIL) under a set of rules prescribed in regulations A section of the Code dealing with Essential Services further restricts action and increases penalties in such instances.

The Industrial Relations Code was introduced to manage emerging conflicts. It is an all embracing statute transplanted by colonial administrators, containing elements of choice that focussed power in the hands of the key official, the colonial administrator and subsequently the relevant Minister. In turn, the Code created further conflicts, as these choices were exercised. The BKATM - government dispute in 1980 is the classic case study of these developments.

\section{The 1980 BKATM strikes and outcomes}

Although the Trade Union Ordinance has been in place since 1946, and trade unions had developed, albeit without overt government encouragement, very few collective agreements have been made in Kiribati. One such agreement was signed in 1975 with a union representing plantation workers at Kiritimati Island, another in 1978 with the British Phosphate Commission covering workers on Banaba (Ocean Island). Prior to independence terms and conditions of employment in the public sector were determined initially by the administration, sometimes after consultation with the Civil Service Association, sometimes after a consultant's report, and sometimes after industrial action by workers. For example, a two-day strike by unestablished staff in Tarawa in November 1962 expressed dissatisfaction over a salary award (Pacific Islands Monthly, December 1962). In 1974 a strike by waterside workers preceded concession of a bonus system associated with cargo handling.

A tension that exists in emerging and newly independent states is the relationship of trade unions, trade union leaders and politics. In Kiribati the emerging unions of the 1970 s were important power bases for local politicians, and for challenges to the colonial status quo. During this period the BKATM rallied the indigenous public sector employees, and was an 
important source of opposition supporting the interests of workers against the state as an employer. The passage of the Industrial Relations Code in 1974 was a direct result of increasing union militancy, consistent pursuit of improvements in pay and conditions of service, and increased protection of members against indiscriminate redundancies and premature retirement.

The union movement, particularly the BKATM, also provided a base of political opposition within the established House of Assembly, both before and after the attainment of internal self-government in 1977. But the election of this (apparently) union-supporting opposition group to government in 1978 was to be disappointing and frustrating. Several union leaders became part of the new government, one, the original organiser of the BKATM (Abete Merang) became Minister of Labour and Manpower, another, Minister of Works. Ieremia Tabai, Chief Minister in this last pre-independence government, and later to become the founding President (and government leader) of the independent Kiribati, had also been closely associated with the trade unions during the period in which he was opposition leader in the House of Assembly. After independence the Tabai government first resiled from close contact and involvement with the BKATM, and then seriously challenged the actions and role of that union.

Within the public sector a codified National Conditions of Service had developed and during 1978 - 1980 various procedures, an overseas consultant's review and report, an Incomes Commission and arbitration, were utilised in an attempt to resolve the direction and substance of change in this code. As time passed disputation increased rather than diminished. Argument about substance, the outcomes from each process, was but one aspect of the disputation. Delays in ministerial action, the choice of procedures at each point and the selection of personnel to participate in each procedure, individually and collectively, added to the scope of disputation. Further disputation arose over varying interpretations as to whether outcomes of specific processes (e.g., a report) was a set of recommendations subject to further negotiation, or a non-negotiable set of terms and conditions.

Eventually a one-day unlawful strike, and a five-week lawful stoppage, occurred. Awira describes the events of the latter strike in detail, but the atmosphere is well encapsulated in the following extract:

The strike went on for five weeks and it proved a nightmare experience for the whole country. The powerhouse attendants withdrew their labour and the police mechanics took charge of powerhouse operation. The shipping and port services were disrupted, including the servicing of overseas ships. Arson and sabotage of public property were rampant, several buildings were set on fire and a trade union member was shot by police during a night chase. The KG [Kiribati government] introduced emergency measures, including the recruitment of extra policeman, during the strike to combat militant action by the union.

The union members spent most of their time fishing to support their families, however the loss of pay to the strikers began to take its toll from the third week. (Awira, 1988, p. 38)

Direct political involvement in the form of a directive to dismiss 500 striking workers further exacerbated the situation. Then, despite the lawfulness of the strike, the Minister refused to recognise these dismissals as a trade dispute under the Industrial Relations Code. Protest was to no avail and the strike collapsed as a crushing defeat for the BKATM.

In the aftermath of these events government moved to address the perceived weaknesses of the Industrial Relations Code, and inter alia took measures intended to increase employee input into problem solving at the workplace, and to establish a pro-active 
mechanism for considering and determining changes to the National Conditions of Service.

Two committees were established, the Management Consultative Committee (later called the Joint Consultative Committee or JCC) and the Standing Review Committee (SRC). The JCC is an umbrella term for committees, established in Ministries and government trading agencies, with a broad consultative role. In particular, it provides a forum for discussion of ways of improving efficiency, productivity, safety measures and working conditions, for sharing information about policies and decisions which affect the workforce, for an exchange of views on all aspects of the work of the organisation, for discussion (but not determination) of claims affecting conditions of service of either all employees or a specific group of employees, and to handle workplace grievances (not resolved by discussion at the employee/management level). The Personnel Officer, Divisional or Section Heads and the Secretary (Ministries) or Manager (trading activities) represent management on the committee. Employee representation comprises one or two persons from each division or large section of the organisation.

The SRC, the second level of the structure, comprises four senior public servants, the Secretary to the Cabinet (head of the Civil Service), the Secretary to the Ministry of Trade, Industry and Labour, the Secretary for Finance, and the Deputy Secretary (Personnel Division). The main ongoing task of this committee is to recommend to Cabinet changes in the national conditions of service referred to it from the Joint Consultative Committee structure, and responsible senior officers.

While in principle consultative processes were improved by these structural changes, several areas of concern continued. In particular, the role of trade unions in the processes, the insertion of a further range of procedures to be utilised before one or more of the multiple choice procedures of the Industrial Relations Code might be implemented, and assessing the tokenism or reality of the consultation, became part of an on-going debate.

\section{Pressures for further reform}

A minimum degree of overt industrial strife characterised the years immediately following the 1980 BKATM strikes and establishment of the consultative review committees. It is agreed that the lengthy strike was a traumatic event in a small developing micro-state. It is not accepted, however, that disagreement and disputation disappeared. Pressure for further reform continued. Rebounding from the disaster of 1980 the BKATM slowly re-established its own position, and then worked to develop a co-ordinated trade union approach through the formation of the Kiribati Trade Union Congress (KTUC). The BKATM and the KTUC, to a lesser extent, were central to the on-going campaign for further reforms, especially arguing for a positive role for unions in industrial relations processes, and, more significantly, as a partner in national development. Teachers and nurses unions, which had refused to support the BKATM in the 1980 strike, were ultimately convinced of the need for reform and affiliated with the KTUC.

A seminar held in Tarawa at the University of the South Pacific Extension Centre on 5-7 June 1989 was an important and visible step in this campaign. The Ministry of Trade, Industry and Labour (MINTL) joined the BKATM and KTUC in sponsoring the seminar. Funding support was provided from the New Zealand Public Service Association. Twenty-seven participants were involved. Sixteen of these represented the main trade unions, and eleven were personnel officers/managers from a range of government ministries and 
trading agencies. The author had been invited to chair the seminar, acting in a facilitator/resource person role. Dr Anote Tong, Director of the Atoll Research Unit of the USP on Tarawa was secretary to the seminar. The seminar was conducted in English and Gilbertese with translation. The use of the Gilbertese language was important in adding to the range of contributions, especially from trade union speakers.

Although the seminar had been the initiative of the unions, the eventual co-sponsorship by MINTIL, and the broad participation of government personnel reflected government acceptance of the relevance of the initiative, if not of the view about the need for and possible direction of change. MINTIL reinforced each of these points; the first by presenting an opening address and welcoming discussion, and the second by suggesting that, as a matter of substance, some fine-tuning of the JCC structure was all that might be needed. Further position papers were presented by a representative of the Ministry and the President of the KTUC. The Ministry argued for a clear delineation of role between the Labour Officers of MINTIL and the Public Service Commission (PSC), in respect to the administration of the public service and responsibility for public employment.

The trade union position was a case for more radical change. It argued that the 1980 BKATM disputation had demonstrated the weakness of the multiple choice mechanism of the Industrial Relations Code, and that the Code required drastic revision. Further the JCC format had operated to minimise union involvement, and the SRC (where key recommendations developed) refused to allow union input. These committees it has been noted, acted to create new terms and conditions of employment, and process grievances arising from the application of existing terms and conditions. The union position noted three main areas of concern.

First, if the trade unions could not participate in the processing of grievances until JCC procedures had been exhausted, the chances of a constructive and positive role for the unions in dispute resolution was minimal. Inevitably the union was forced to challenge results rather than pursue mutually acceptable solutions. Second, in so far as the JCC/SRC structure established new terms and conditions, it acted as a substitute for collective bargaining. Third, the isolation of trade unions from policy making at the SRC and government level, failed to recognise the willingness and capacity of the unions to be involved in tripartite consultative planning in the national interest. Without decrying the importance of the third issue, the seminar, perhaps pragmatically, accepted a more limited role and focussed on a review of the processes of dispute resolution at the micro-level.

Initially the disparate position of the key parties, with the unions focussing on major reform and government/management on oiling the wheels of the current institutions and procedures, created an air of potential futility. The breakthrough came in an unexpected way, when the participants separated into groups to discuss the traditional i-Kiribati approach to resolution of family conflicts. If discussion did not resolve disputes within a family then elders of the family would become involved in the process. In the case of disputes between families another person or group from the village would be available to provide assistance. If the dispute could potentially affect the entire village community then settlement would involve the "old men" sitting in the Maneaba (meeting house) with each family having a voice through their representative (booti.) If agreement was not reached a pronouncement would be made by the "old men" sitting in council.

The seminar recognised that processes of negotiation, conciliation/mediation and arbitration were central to the traditions of dispute resolution for the i-Kiribati. Moreover, there was an identification of a specific process for a particular type of dispute and, if needed, a natural progression of stages towards final resolution. 


\section{Kevin Hince}

The multiple choice of processes bequeathed by the colonial legislation was a complex antithesis of a simpler and predetermined set of processes. The Maneaba, the meeting house, was the traditional institutional framework for each of these processes, indicating a role for a predetermined acceptable institutional facility for dispute resolution. It is interesting to note that in traditional Kiribati society a failure of the discussions and decisions of the Maneaba to resolve the issue could lead to outright conflict (fighting) between the families. With some humour, but clear understanding of the coercive similarities, participants equated the modern notion of 'the strike' to this fighting, suggesting that the availability, potential, and ultimate threat of a withdrawal of labour could play a key role in provoking an earlier settlement.

It was at this point that the complexities of the Industrial Relations Code and the unilateralism of the JCC and SRC were recognised, and the focus of the seminar shifted to establishing an agreed basis of change. Key recommendations, which emerged as a consensus were:

(i) government should be asked to review the Industrial Relations Code, with the assistance of the ILO and in consultation with the KTUC. In the review, amongst other things, particular consideration should be given to the nature of a sequential process of dispute resolution combining conciliation/mediation and arbitration, should discussions (negotiations) break down. Reference was made to the link of such processes to more traditional i-Kiribati practice.

(ii) representation of the KTUC on the SRC (or a sub-committee) as a means of representation for views of workers. Further, that the willingness and potential of the KTUC to contribute positively as a partner in the development of Kiribati be noted, and opportunities for such contribution explored. While the highest priority union issue, the establishment of formal recognition of collective bargaining processes, was not endorsed, the issue of a more positive and accepted role for unions was apparent.

(iii) the development of a standardised procedure which would ensure workers could elect their representative to the JCC, and that legislative protection be accorded workers bringing grievances to the formal committee process.

(iv) that a precise interpretation of the power of the PSC be sought (if necessary from the Kiribati High Court) especially in respect to clarification of apparent conflict between the Industrial Relations Code, the role of MINTIL, and constitutional processes in respect to the Public Service Commission.

In the course of discussions it had become clear that the KTUC seriously questioned the legitimacy and effectiveness of the JCC as a channel for workers grievances. The KTUC were particularly critical of the frequent practice of management selecting worker representatives. However, management participants, especially from the trading agencies, expressed support for the JCC process, and after discussion it was agreed that the consultative process did serve a useful role. The focus of the third recommendation was therefore on improving rather than abandoning the framework.

The basis of the fourth recommendation was the recognition that the resolution of several identified grievances had been delayed, because of inter-ministry rivalry. The PSC had been established under the Constitution with the responsibility for the administration of 
public employment. The PSC claimed unilateral and final rights and power in a number of areas of such employment, including dismissals. The union, supported by informal views of the MINTIL, argued that the procedures of the Industrial Relations Code should be available as an appeal path. When these contrary points of position were debated at the seminar the need for a resolution was identified, and the recommendation referred to above resulted.

Soon after the seminar the Minister of Trade, Industry and Labour indicated acceptance of the validity of the recommendations, without expressing a commitment to change. To date nothing final has happened, but 1989 was the year of celebration of the tenth anniversary of independence, and in 1990 Kiribati hosted the South Pacific Forum. Impending presidential elections, more critical than normal because Ieremia Tabai, the founding President, was excluded by the constitution from seeking a further term of office, was a central issue during 1990. Such events were individually, and collectively, of much greater political significance than the outcome of the seminar.

Anote Tong (letter to author, September 1989) foreshadowed a degree of inactivity, writing:

.... unless incentives are provided or a crisis occurs it is unlikely that initiative will be taken

in the immediate future. In order to make further substantial progress it will be necessary

to continue to pressure the Ministry, particularly while the memory of the commitments

made at the workshop remain fresh.

Some informal change did occur with the appointment of an ad hoc conciliator to seek resolution in several long standing disputes which had been discussed at the seminar, and provided the impetus for the fourth recommendation above. Such action was a step, albeit a small step, in recognising conciliation rather than unilateralism, as a preferred procedure in processing industrial disputes in Kiribati.

A trade union seminar, conducted in Tarawa in February 1990, under the auspices of the International Confederation of Free Trade Unions (Asia and Pacific Regional Office), revisited the theme of reform of industrial relations, thus indicating that the issue had neither been resolved, nor forgotten. The same seminar addressed the emerging issue of the impact of 'privatisation' of industrial relations in Kiribati. The Sixth National Development Plan (1987-1991) had foreshadowed such developments. In 1988 ownership of telecommunications had been transferred from the Ministry of Transport and Communications to a government-owned company, and management had been entrusted to an overseas corporation. By early 1990 plans for private sector equity participation in telecommunications had been developed. In addition, a number of other government enterprises, the government printery, the airline, shipyard, foodstuff importing and copra exporting, were in various stages of restructuring prior to a potential progression to privatisation. The union seminar identified issues of concern, called for an education and awareness campaign amongst workers, argued for a consultation process involving unions and government, and began to enunciate certain rights (no redundancy, preservation of wages and working conditions, retraining etc) that it believed should be protected.

Despite Anote Tong's pessimism a process for considering change has been implemented. The International Labour Organisation had been involved for several years in a review of the requirements for health and safety legislation, and recommendations were made to government on this matter in early 1990 . The ILO was then invited to review the Industrial Relations Code, and a visit by an ILO Mission for that purpose occurred later that year. The KTUC and the Chamber of Commerce were consulted. A report was delivered to government early in 1991, in the last months of the Tabai government. The election 
campaign, a new government and President, has delayed consideration of the report. At the time of writing (December 1991) the report itself has not been made public. One major change that is anticipated is the establishment of a clearly defined route for processing grievances, with an Employment Court as a definitive final step. The Court will be part-time, and the expectation is that unions and the Chamber of Commerce will be consulted about the appointment.

It was not expected that the ILO mission would recommend the adoption of a formal process of collective bargaining to determine wages and conditions of employment in the public sector, or the inclusion of the KTUC in the procedures of the Standing Review Committee. The inference left by the Mission during discussions with the KTUC was that such steps were considered matters for government to decide, as and when appropriate. Nevertheless, issues such as the role of trade unions, and the relevance of consultation in national development and macro-change, are now part of an open public debate. Since 1987 the overall degree of change has been minimal and the speed of change has been slow, but the direction of change has been inclusive rather than divisive. The responses have been different than in the period during, and immediately following, the BKATM-government confrontation of the early 1980s. An optimism exists that a pluralist, tripartite approach to economic planning, to changes in work organisation, and to industrial relations processes and institutions, will be adopted as the pattern for Kiribati in the approach to the 21 st century.

\section{References}

Awira, N. (1988), The 1980 BKATM Strike and Its Implications on the Development of Industrial Relations in Kiribati, Unpublished research report, Diploma in Industrial Relations, Victoria University.

Hince, K.W., (1971), Trade Unionism in Fiji, Journal of Industrial Relations, 13(4): 368-389.

Kiribati Government (1987), Sixth National Development Plan, 1987-91.

Pacific Islands Monthly (various issues).

Roberts, B.C. (1964), Labour in the Tropical Territories of the Commonwealth, London, G. Bell and Sons. 